\title{
Perspectives in Urban Planning Research: Methods and Tools
}

\author{
Janes Ouma Odongo ${ }^{1,2^{*}}\left(\mathbb{D}\right.$, Donghui $\mathrm{Ma}^{1}$ \\ ${ }^{1}$ College of Architecture and Urban Planning, Beijing University of Technology, Beijing, China \\ ${ }^{2}$ Department of Government and Legal Studies, The Technical University of Kenya, Nairobi, Kenya \\ Email: *odongojanes@yahoo.com
}

How to cite this paper: Odongo, J. O., \& Ma, D. H. (2021). Perspectives in Urban Planning Research: Methods and Tools. Current Urban Studies, 9, 759-778.

https://doi.org/10.4236/cus.2021.94045

Received: September 27, 2021

Accepted: December 7, 2021

Published: December 10, 2021

Copyright $\odot 2021$ by author(s) and Scientific Research Publishing Inc. This work is licensed under the Creative Commons Attribution International License (CC BY 4.0).

http://creativecommons.org/licenses/by/4.0/ (c) (i) Open Access

\begin{abstract}
The physical urban terrain across cities continually evolves through insights, consultations, deliberate redesigning or random acts by community members and natural forces that reshape the urbanscapes and how urban spaces are used. These built urban environments, including the quality of air, water and infrastructure therein, determined through research-informed designs and redesigns, are aimed at suiting the needs of space users in consideration of their social, psychological, political, cultural, financial, physical and such other dispositions and needs. Such research methods and tools used in shaping urban planning are also evolving. This paper discusses these contemporary research methods, tools and technology used in an urban planning inquiry. It applies current trends and examples to illustrate the employment of the methods used in researching urban planning to inform the design, development and operation of urban spaces. It is intended to be a valuable introductory reference for emerging researchers in urban planning, especially, undergraduate and postgraduate students with limited previous exposure to urban planning research, who are looking for a consolidated starting point. The authors found this to be largely lacking. Established researchers in the discipline will find the article useful as well. It concludes that future research in the discipline should not ignore established research techniques in addressing urban vulnerabilities.
\end{abstract}

\section{Keywords}

Research Methods, Urban Planning, Tools, Urban Governance, Sustainability

\section{Introduction}

Like all other disciplines, urban planning heavily depends on research to grow 
and evolve, failure to which the discipline can lose relevance and become extinct in today's fast-changing world. This is in line with observations in the Frascati Manual which defines research and experimental development as comprising of creative work undertaken on a systematic basis in order to increase the stock of knowledge of man, culture and society; and the use of this stock of knowledge to devise new applications (OECD, 2002). Like the manual, (Gulbrandsen \& Kyvik, 2010) identified three major universal research methods applicable in both the physical and social sciences. This paper will adopt as the key research methods in urban planning namely: 1) basic research; 2) applied research; and 3) experimental development.

Other than the three methods listed above, (Parnell \& Piertese, 2015) identified pure research, applied research, embedded research, city labs, professional networks, cityscapes and exhibitions as important modes for generating urban planning-related new knowledge. This section of the paper will discuss the first three in detail with embedded techniques and relevant examples, and then proceed to provide a synopsis of the rest which the readers can research more on. Some of the latter modes identified by (Parnell \& Piertese, 2015) will be explained in the section of research technologies and tools which follow.

\section{Research Methods in Urban Planning}

\subsection{Basic Research}

Also known as pure or fundamental research, basic research refers to research designed and oriented towards exploring and explaining the basic principles behind the ordinary functioning of the world. The OECD (2002) defines basic research in the Frascati Manual as experimental or theoretical work undertaken purely so as to acquire new knowledge of observable phenomenon and the underlying facts in them. The research is elaborative in nature and intends to satisfy user curiosities by explaining what others would consider to be scientific miracles. In doing this, it increases the existing base of scientific knowledge by presenting theoretical perspectives (or alternatives) to explain certain phenomena or behaviour in society (Palys \& Atchison, 2021). It unearths facts surrounding people, things, or statuses to expand human understanding of them (OECD, 2002).

Palys (2018) states that pure research is not problem solving but fundamental in nature. It tries to justify the status of a phenomenon whose applications may or may not have any use in the immediate or long-term future. According to (Parnell \& Pieterse, 2015), it seeks to enhance an understanding of past legacies through an analysis of diverse aspects of urban complexity such as culture, social identities, resource flows, labour regimes, regulations, urban politics, welfare regimes and the design of a city. Pure research in urban planning therefore entails the engagement, often by the philosopher kings (those of high intellectual caliber) of the discipline, into examining existing theories explaining certain phenomena, redesigning these theories, or, where they are found plausible, coming 
up with alternative theories to offer better explanations. Similarly, the researchers can examine completely new phenomena and propose new theories in areas that had not been explored before. Such would include the current drive to have green urban infrastructure to combat global warming, or studies to develop theories on smart cities (Palys, 2018).

Pure research intends to widen knowledge on a phenomenon by exploring and explaining its fundamental principles. In urban planning, this can be in order to expand the theoretical basis around its explanation with the belief that the more understood something is, the better it can be utilized to serve society's functions. Such studies, based on the nature of personnel and resources involved, are often undertaken by universities and other higher caliber research centers. This characteristic has however been reduced by increasing collaboration between academic institutions or academicians with private entities which consume their consulting research services. It is therefore not unexpected to find private commercial and other entities engaging in pure research as well resulting in theoreticians being drawn from there (Palys, 2018).

By nature, pure research is undertaken to feed curiosities existing in researchers. Consequently, they may not have any immediate commercial benefits, but are additionally likely to result in new ways of doing things (innovations) that then feed into investments and remodeling of the way things are done. An example would be developing a new chemical formula (ingredients) for the manufacture of cement which then makes it stronger, faster drying, crack free and resistant to quakes. This can be a research experiment purely aimed, initially, at redefining knowledgebase around cement manufacture. In the end, such can result in commercial benefits (through innovative products) and even extensive applied research as curiosity and interests in its manipulability build (Palys \& Atchison, 2021; Palys, 2018). Through pure research, old theories, standards or formulae such as those guiding cement manufacturing or concrete mixing can get tested and those found to be incomprehensive (or nonsensical) discarded. Another example is the redefinition of causes and effects of urban social decadence where theories explaining such social deviances get reorientated.

Pure research can be exploratory in nature seeking to gain more knowledge on a subject so as to identify problems that could be studied in future. One such example would be a venture to establish the oldest recorded urban history of the world. Here, a researcher can conclude from archaeological explorations and literature review that urbanization began in the Uruk Period (4300 - 3100 BCE) in Mesopotamia, for instance. However, other studies on the subject may come up with an earlier or later date from other future or ongoing exploratory investigations of this phenomenon. Such studies will adopt an exploratory research design.

Other than being exploratory, primary research can be descriptive in nature as well. In this case, the phenomenon under investigation is observed and described without the researcher manipulating it in any way. A good example here would 
be the many studies conducted on ancient Egyptian and Roman cities, or those describing achievements of the green city movement just for the sake of it. Studies have equally been conducted to document and report on the urban planning contributions by scholars such as Le Corbusier, Ebenezer Howard or Frank Lloyd. Such descriptions result in the emergence of theories associated to these scholars. Finally, pure research can also be causal in nature. Causal research seeks to explain the cause-and-effect relationship existing between two variables as would be the case on studies on the cause and impacts of urban sprawl or city beautiful movement. Pure research largely involves observation, polls/surveys, interviews and focus group discussions as its primary means of investigation. Secondary research methods used here include online searches, literature searches and case studies (Palys, 2018; Parnell \& Pieterse, 2015).

\subsection{Applied Research}

Unlike pure research, Palys (2018) as well as Baimyrzaeva (2018) state that applied research is practical and is aimed at offering immediate solution to an existing problem. It bases its studies on pre-existing theories and assumptions made while undertaking pure research (pre-existing knowledge) to address real world problems. It is hence problem-solving in nature (OECD, 2002). It aids decision making and hence, enables the development of policies and programmmes to address a particular problem. Here, in urban planning in Sub-Saharan Africa, (Parnell \& Pieterse, 2015) state that researchers would "engage with decision makers; influence the development agenda to advance a stronger urban focus; assert the normative base of African urbanism; and impart useful knowledge and skills to urban practitioners." Applied research hence goes hand in hand with the offering of advisory services; whether in-house or through external consultancy services (Parnell \& Pieterse, 2015). Its scope can range from large scale surveys to highly complex and intricate lab experiments which unlike the theoretical pure studies, aim to solve specific down-to-earth problems facing individuals, institutions and communities (Palys \& Atchison, 2021; Baimyrzaeva, 2018; Gulbrandsen \& Kyvik, 2010; OECD, 2002).

Perhaps an illustration here would help. With the boom of megacities in $21^{\text {st }}$ century for example, urban security and governance becomes a challenge. It is economically unsustainable to have enough labour force to clean urban spaces, control traffic, monitor crimes and undertake arrests. Consequently, smart technologies are researched on and developed to provide efficient street cleaning solutions. As a result, today's cities have street lights and pedestrian as well as vehicular traffic monitoring cameras to police the streets. Artificial Intelligence (abbreviated AI) is then employed to virtually track and penalize law breakers using system automations with limited human involvement, making policing standardized, easy and dependable (Jiang, 2021; Jiang et al., 2020; Himmelreich, 2013). A similar example is ongoing research across the globe geared towards redesigning urban transport infrastructure to eliminate or reduce traffic jams and 
reduce wastage of urban manhours. As a result of these studies, new road designs are being introduced. In addition to these, alternative transport solutions such as light rails, affordable public buses and trains, autonomous vehicles, cab sharing, decentralization of city central business districts, smart traffic management technologies, drones, rationing of road use, road use levies, construction and use of ring roads and bypasses and subway systems, as well as work-fromhome programmes have been adopted by cities and other entities (Sotra, 2020; Makino et al., 2018).

Applied research undertakes an inquiry into problems that: 1) reflect felt needs; 2) address non-hypothetical problems that are based on factual evidence; 3) suggests meaningful solutions and testable hypothesis to ensure it ultimately alleviates the existing problem; and 4) are relevant and manageable (Andrew \& Hildebrand, 1983). This is illustrated by the examples given in the preceding paragraph. And to deliver the above four, (Bickman \& Rog, 2008) identifies three types of applied research within the social sciences. These include descriptive, experimental and mixed method studies. All the three types require planning and execution which entails defining the research problem, planning the study, execution (entailing data collection and analysis; or experimentation and verification) and reporting on findings with follow up to ensure emanating conclusions and their recommendations are applicable in solving real life problems (Bickman \& Rog, 2008). They summarize the applied research process as shown in Figure 1 below:

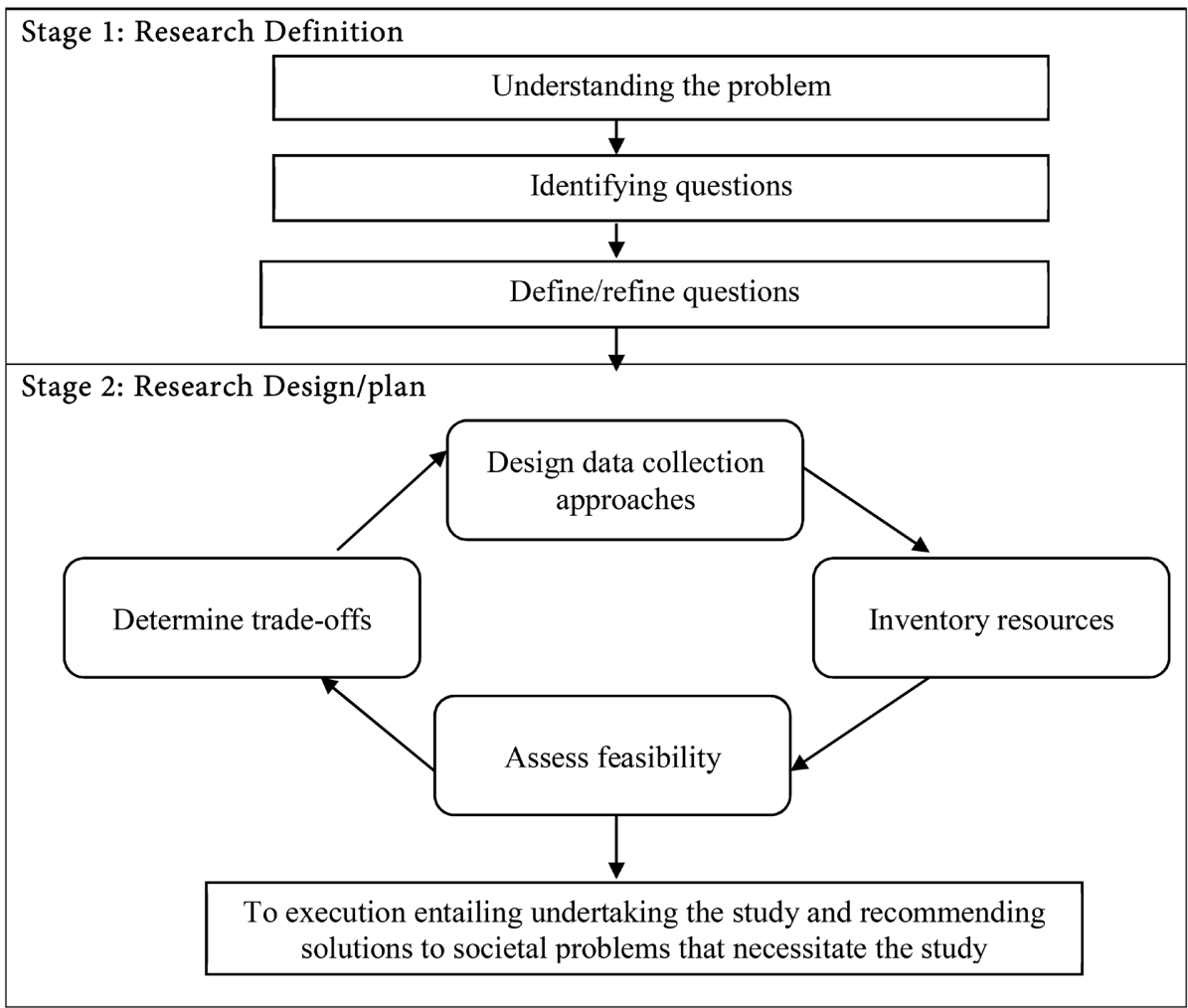

Figure 1. The applied research process as outlined by (Bickman \& Rog, 2008). 
(Bickman \& Rog, 2008) state that descriptive designs paint a picture (description) of a phenomenon as it naturally occurs without any manipulations so as to answer questions that either describe one variable (univariate), compare a variable to a particular standard (normative) or summarize the relationship between more variables (correlative). Descriptive studies do not explain the cause-andeffect relationships between phenomena. Instead, they simply document what was or what is so as to enable sound decision making using this information. Achieving this depends heavily on the representativeness of the sampled data which will then guarantee validity of findings. Examples of univariate studies include ethnographic research where the researcher immerses himself into a particular urban community to understand their shared culture, conventions and social dynamics (Caulfield, 2020).

Like demographic studies, there are correlational studies which simply report negative, positive or zero correlation between variables (Bhandari, 2021) such as poor housing and increased urban crime rates as could be hypothesized in Nairobi's Kibera or Dandora Slums. There are also cross-sectional studies which collect data from many divergent individuals, groups or geographical locations on the same theme at the same time in order to document a variation or consistency in variables under observation (Thomas, 2020a). One would in this case consider examining the impact of the COVID 19 pandemic on urban mobility (or on the mental health of urban dwellers) across the cities of Nairobi, Beijing, New York, Windhoek, Wellington, Calcutta, Canberra, Cape Town, Rio de Janeiro and Ottawa between January 2020 and December 2021. The outcome of such a study would be a description of impacts across geographies that would then inform policy and programming decision making; with the hope of alleviating the suffering being experienced in each place. The decisions to be made from such, for example, would be about which city gets more financial and technical resources for mental health awareness and counselling programmes.

Further designs include longitudinal studies in which a researcher observes the same individual, population or geographical area over a period of time to document changes (Thomas, 2020b). For instance, one would want to know the impact of vaccination or mask use in reducing COVID-19 caseloads in Montreal, or the contribution of affordable housing programmes to reducing urban crime in Casablanca over a one- or five-year period respectively. But these longitudinal studies can exist as case studies as well. In themselves, case studies detailed qualitative and/or quantitative examination of specific subjects "such as a person, group, place, event, organization, or phenomenon" with the aim of "describing, comparing, evaluating and understanding different aspects" about them (McCombes, 2019). Whereas longitudinal studies take a historical approach to their examination, case studies do not have to. They simply examine a phenomenon. One such is an examination of how increasing road coverage (by width and network) increases transport efficiency in cities using Lusaka as a case from where a summative conclusion can be derived. 
In all the above descriptive studies, the researcher does not manipulate or influence the variables. They are observed in situ. The programmes that were going on such as public spending on housing, road construction or artificial intelligence will just go on and the researcher's work is to observe and report how they affect other aspects of urban governance. On the other hand, where the researcher decides to manipulate variables in order to report the impacts of such manipulations, the studies will shift from being descriptive to being experimental (Bhandari, 2021; Caulfield, 2020; Thomas, 2020a; Thomas, 2020b; McCombes, 2019). Experimental research design, therefore, denotes instances where changes in dependent variables are examined against the independent one(s) through randomized experiments (Stephen, 2020; Gulbrandsen \& Kyvik, 2010). Quasi-experimental designs on the other hand engage pre and post treatment observations to the experiment in order to observe the outcomes of introducing nonequivalent experiments. Nonequivalence arises because participants in these experiments are usually not randomly selected (Thomas, 2020c; Stephen, 2020; Gulbrandsen \& Kyvik, 2010).

\subsection{Experimental Development}

Klosterman (2015) defines experimental development as manifested in urban planning through the design and redesign of multidecadal land use maps. These maps are a corner stone of urban planning research and development. They have existed since the emergence of the discipline in the mid-20 $0^{\text {th }}$ Century. Cities still depend on these maps, which are now largely digitally produced, to determine their land use regimes. On the other hand, (Gulbrandsen \& Kyvik, 2010) generally identify experimental development as the third of three major research methodologies after basic and applied research. They, like the Frascati Manual(OECD, 2002: p. 77) define experimental development as:

"Systematic work, drawing on existing knowledge gained from research and/or practical experience, which is directed to producing new materials, products or devices, to installing new processes, systems and services, or to improving substantially those already produced or installed".

The primary mandate of experimental development, as a research tool, is to make technical improvements on products or processes. Consequently, experimental development as a research approach aims at filling exiting technical and technological knowledge gaps which may improve existing tools and technologies, or innovate new ones to be used in addressing societal problems (Gulbrandsen \& Kyvik, 2010; OECD, 2002). A good example in AI is the development of image processing technologies used in urban policing, or those used to process virtual payments using fingerprints or eye contact. Such have enabled the booming growth of online shopping in $21^{\text {st }}$ century cities. Similar technologies exist for tracing lost cars, presenting geographic data such as accurate maps and geographic information systems which have become very necessary for navigating the global 
mega cities. Additionally, experimental developers work to innovate alternative modes of transport and communication, new architectural designs for urban spaces, alternative environmental conservation and restoration approaches in urban and rural communities, and other mechanisms for community/public participation in urban planning and governance. The hope of these researchers, is always that their new prototypes will get relevance, acceptance and use in addressing the issues they were meant to tackle (OECD, 2002). Initially, designs intended to address urban ills such as poor "transportation access, reducing urban blight, and improving social and economic conditions at the urban and regional scales" (Klosterman, 2015).

In most cases, experimental developments come up with tangible products as opposed to mere notes or reports. They are undertaken by passionate individuals whose goal is to change the day to day running of things (business and operating models). Their outputs can be software, hardware or techniques/maneuvers for using such existing products to increase efficiency and effectiveness in service delivery. The OECD gives examples similar to the following (see Table 1 below) which can help us distinguish between basic, applied research and experimental development. As we can see, there is some clear transition from one to the next, which would suggest the order in which research should flow.

According to OECD, the major distinction between development research and actual development is that the research's main goal is to discover, generate or develop prototypes which will go into molding the actual developments. As an illustration, it is from a researcher, developer toying with various phone improvement ideas that a mobile phone came into being. Subsequent such toying with

Table 1. Relationship between basic research, applied research and experimental development.

\begin{tabular}{|c|c|c|}
\hline Basic research & Applied research & Experimental development \\
\hline $\begin{array}{l}\text { Examining the motivations } \\
\text { for rural to urban migration }\end{array}$ & $\begin{array}{l}\text { Investigating the socio-economic forces resulting } \\
\text { in rural-urban migration in order to come up } \\
\text { with programmes to halt the rural labor drain }\end{array}$ & $\begin{array}{l}\text { Development and testing of a programme of } \\
\text { financial assistance and expansion of services to } \\
\text { rural communities to prevent rural migration to } \\
\text { large cities }\end{array}$ \\
\hline $\begin{array}{l}\text { Study of the role of } \\
\text { technology in reorienting } \\
\text { work, school and home } \\
\text { lives of urban dwellers }\end{array}$ & $\begin{array}{l}\text { Study of the role of technology in reorienting } \\
\text { work, school and home lives of urban dwellers in } \\
\text { order to develop remedies for physical health and } \\
\text { fitness }\end{array}$ & $\begin{array}{l}\text { Development and testing of equipment and } \\
\text { programmes to stimulate physical fitness and } \\
\text { reduce obesity cases among urban dwellers in the } \\
\text { wake of technology dependent living }\end{array}$ \\
\hline $\begin{array}{l}\text { Study of the composition } \\
\text { and structure of the family } \\
\text { in different civilizations } \\
\text { past and present }\end{array}$ & $\begin{array}{l}\text { Study of the composition and structure of past } \\
\text { American or African families and how this } \\
\text { helped maintain social order so as to recommend } \\
\text { remedies for current and future urban social } \\
\text { decadence }\end{array}$ & $\begin{array}{l}\text { Develop and test of policies and programmes on } \\
\text { parenting models that can help maintain a } \\
\text { standard family structure in urban households so } \\
\text { all children get motherly and fatherly guidance } \\
\text { and mentorship }\end{array}$ \\
\hline $\begin{array}{l}\text { A study of the origin, cause } \\
\text { and impact of urban solid } \\
\text { waste management }\end{array}$ & $\begin{array}{l}\text { An examination of the impacts of poor urban } \\
\text { solid waste management on flush flooding risks } \\
\text { so as to develop remedies and built urban flood } \\
\text { resilience }\end{array}$ & $\begin{array}{l}\text { Development and testing of urban street vending } \\
\text { and solid waste management infrastructure that } \\
\text { can be used to reduce, reuse, collect and recycle } \\
\text { solid wastes efficiently }\end{array}$ \\
\hline
\end{tabular}


mobile phones have made them smaller, smarter and more complex. Today, the supposed-to-be ordinary calling hand gadget has very many roles. It has money wallets, internet access, is a GPS device, a library, a shop, a watch, a television, a movie theatre and so many other uses that resulted from experiments that design and redesign these gadgets. Same can be said of the development of airplanes which have significantly improved travel and movement of goods and services between cities across the globe, hence improving and standardizing the urban experience. Continuous experimental research in factories is similarly accountable for increased array of goods available in city stores. Furthermore, it has resulted in improved quality and better packaging of these products. Today, it is more common to have development research undertaken through computer-based simulations unlike the real physical developments. Using AI, such can predict and correct errors in project design before implementation saving resources. Through this, actual investments in urban physical, social and economic infrastructure (fabric) become more consequential (Klosterman, 2015).

\subsection{Embedded Research}

As earlier stated, (Parnell \& Pieterse, 2015) identified embedded research as one of the significant modes of undertaking urban planning studies. This approach entails close partnership between researchers and practitioners in the field to co-produce outputs for society's gains. It therefore seeks to align field practices with theory to address any likely challenges in the use of developed technologies and practice models. Consequently, embedded research is a bridge that allows mutual collaboration and benefits between academia, academics and academic knowledge with development organizations. It exists in acknowledgement that whereas academics are the fountain of knowledge, industry practitioners are the embodiment of hands-on skills and experience in designing, developing, using and maintaining gadgets and systems. A collaboration and cooperation between these two worlds hence produce valuable insight for both through a give and take interaction (Klosterman, 2015).

(McGinity \& Solakangas, 2014) report that the concept borrows from embedded journalism practiced by US media reporters on the American invasion of Iraq in 2003 wherein they had to be within the war environment and update their audiences. The practice is very handy considering this article's earlier remarks on how most of the innovations in urban planning and governance take place in the industry. They occur in capitalist enterprises as opposed to universities and government research labs (Smart City Hub, 2017). Such innovations have been very vital in improving public health, medicine, social welfare, access to justice, public participation, training of urban planners and improving the quality of urban infrastructure (WHO, 2018; Cheetham et al, 2018; Raven et al, 2018; McGinity \& Solakangas, 2014; Lloyd et al, 2013; Wey, 2011). 


\section{Contradicting Opinions on the Research Methodologies}

Despite the clear distinctions between research methods and designs explained above, Palys (2018) and (Palys \& Atchison, 2021) insists that these categorizations of studies as either pure, applied or experimental is strictly based on the motivation that compels a researcher to undertake a study at the beginning. Contrarily, the actual research outcomes can be different. Even pure research, can end up bring practical solutions to daily problems by eliciting new thinking and new actions. These will follow the reorientation of theoretical thinking around the phenomenon as already seen. On the other hand, (Gulbrandsen \& Kyvik, 2010) argue, based on their study of perceptions among academics in Norway that there is very limited difference between basic research, applied research and experimental design. I would however agree with Palys (2018) in this case. The motivation of these studies varies at the beginning indeed, although one can end up elsewhere in the course of undertaking their study. An applied study or an experimental development undertaking can reorient theoretical thinking around a subject, in the same way that basic research can end up bringing forth applicable models in running society's affairs. Knowledge is the mother of all inventions which themselves generate new knowledge.

It is the key to note too that applied research and experimental development work does not necessarily have to take place in university labs. Some of the key innovations driving the urban growth and development agenda today did not even originate from urban planners. A good example of such today includes online shopping which apart from delivering variety of products to consumers at the convenience of their homes, rids cities of traffic by all city dwellers crisscrossing streets in search of goods and services. Instead, a few scooter, tuk-tuk (or auto rickshaw) and truck drivers do all the work. This also reduces the pollution resulting from heightened human activities (such as driving) within urban spaces. Such has been the experience of cities such as Beijing, London and New York. Cities of the Global South such as Nairobi, Sao Paulo, and Jakarta are picking up the online shopping boom and craze too (Pettersson et al., 2018; Alves et al., 2017). E-commerce has been very vital in helping the world's cities and their residents cope with COVID-19 pandemic. It is among the few sectors that experienced a boom as other sectors of economies collapsed due to COVID-19 related restrictions on mobility, work and entertainment (Villa \& Monzon, 2021). Similarly, the rise of online (and sometimes shared) taxi services has reduced the need to drive among many citizens. This, furthermore, reduces the number of cars on the roads across cities. As a whole, the highlighted innovations are a vital contribution to fighting transport related greenhouse gas emission and global warming (Mucowska, 2021; Çetin, 2017).

(Bentley, Gulbrandsen, \& Kyvik 2015) reports a widely held perception among scholars from across the globe that basic research no longer takes place in universities although I think it does based on the many theories that are still emerging in various disciplines among them being urban and regional planning (Elliott, 
2018; Cao, 2013). Similarly, there exist long held views that most of applied research and experimental development work that has produced some of the world's leading innovations in the $21^{\text {st }}$ century across the fields of ICT, Urban planning, architecture, transport, retail, building and construction and governance did not originate within the confines of university research environment (Smart City Hub, 2017). They were produced in private labs of capitalist enterprises keen on bringing a new normal in these fields that they can exploit and make profits (Bodolica \& Spraggon, 2021; Alpaydin et al., 2018; Vidican, 2009). Some of these entities consulted contracted university researchers (Boxall \& Woodgates, 2015; Vidican, 2009). This would then make embedded research to be inbuilt into applied research and experimental development as opposed to being a stand-alone research methodology.

That the universities as entities are not the primary producers of research led innovations points to their deteriorating participation in research and should therefore be reinvigorated. Sustainable research and development of new technologies and practices in community governance (both rural and urban) cannot be left in the hands of capital venturers whose principal motive is profit maximization (Zeleza, 2017). This is risky in a world that is increasingly adopting Public-Private Partnership (PPP) as a means to financing urban and rural infrastructure installation, upgrade and maintenance, and where the needs of the marginalized urban populations are often peripheral to financial gains politicians and investors mint from these PPP arrangements (Odongo \& Donghui, 2021; World Bank, 2020; Nguyen, 2019).

\section{Aggregating Urban Planning Related Data-Key Technologies and Tools}

All the research methodologies and designs discussed above employ qualitative and quantitative approaches of investigation. In quantitative approaches, data collected is aggregated quantitatively (using statistical tools). Here, measures of central tendency and measures of spread are some of the statistical tools that can be used to describe the data. A good example would be a description of the democratic characteristics of urban neighborhoods by gender, age, race and economic capabilities of its occupants. Percentages, range, mean and mode can be easily used to define such population (Schutt, 2018). On the other hand, qualitative analysis of observed behaviour, cues, feelings, characteristics of the population can equally be captured using statements that do not necessarily have statistical values. Such would be aspects such as feelings of joy vis-à-vis sadness, or rejection vis-à-vis acceptance. Reporting that $30 \%$ of neighborhood residents feel happy does not go deep enough into exposing the manifestation of these feelings that can only be qualified using unique individual characteristics.

Pedamkar (2020) identifies five types of qualitative analysis namely: 1) content analysis (interpretative and descriptive); 2) narrative analysis; 3) discourse analysis; 4) framework analysis; 5) grounded theory. Additional ones include qualita- 
tive comparative analysis, case-oriented understanding, ethnography, netnography and ethnomethodology. Some of the technologies and techniques used in collecting urban planning related data today include:

\subsection{GIS and Remote Sensing}

Klosterman (2015) defines GIS as "computer systems for capturing, storing, querying, analyzing, and displaying information about natural and built entities and activities that can be displayed on a map." It connects data to maps and gives adequate descriptions of such data for decision making. Such attribute information on any physical phenomena provided under GIS include "location (beginning and ending points), shape (straight or curved), type (solid, dotted, or dashed), and color. Through GIS, it is even possible to get a three-dimension (3D) view of the actual phenomenon as it appears on the ground. This allows users to understand patterns, relationships and geographical contexts regarding their phenomena under investigation hence delivering efficiency, better communication, reliable decision making, and better management of urban and rural spaces (ESRI, 2021). ESRI reports that GIS can help us identify problems, monitor change, manage and respond to events, forecast future trends, set priorities and understand prevailing undercurrents (e.g., of urban sprawl or infrastructure development over time).

Geographic information systems exist as applications consisting of maps, data and analysis tools. Within the urban environment, these can be used in research and governance (through mapping, design, development, installation, maintenance and daily management) of affairs such as transport, health, education, electricity and water supply, oil and gas infrastructure, security, telecommunication, retail, housing, government, public safety, insurance, manufacturing, waste management and disaster risk reduction in all the above and more areas (ESRI, 2021). Information recorded through GIS (Geospatial data) is often accessed remotely. Remote sensing therefore refers to the process of detecting and monitoring physical characteristics of a geographical location (or geographically located phenomena) remotely (virtually) without making physical contact. Such data (in image form) is usually collected using powerful cameras located in satellites or aircrafts.

\subsection{Labs}

These exist as academic, city, government research or private investor labs which develop models for various types of infrastructure. The models are either produced for the mere experimentation purposes, or as designs to be adopted in developing actual infrastructure such as designs of neighborhoods, houses, landscapes, roads, public spaces and other vital urban infrastructure. They seek to ensure that such infrastructure once constructed, blend well with and serve the communities they are designed for. It is in these labs that environmental, social, political and economic impacts of urban development projects are forecast and treated or planned for. Moreover, the labs are vital for innovating new products, tech- 
niques and technologies vital for urban regeneration and growth. The large-scale urban models, cellular automata (CA) models, agent-based models, and rulebased.

Models identified by Klosterman (2015) owe their origin to such labs. Field experiences play the same role as laboratory simulation. It must be acknowledged that every project or intervention is an opportunity to collect data and inform future undertakings within the same and other similar projects. Subsequent projects often tend to build on the strengths of previous ones even as they avoid their weak points. Ongoing and completed projects are hence a living lab of a sort.

\subsection{Use of Artificial Intelligence}

Sustainable urban planning and governance is dependent on a lot of data that has to be continuously collected, analyzed and feedback ploughed into planning the future of the affected city. Such continuous data collection can be monotonous and expensive engaging a lot of human resource for today's megacities, or even medium sized metropolis such as Nairobi whose population is 5 million or more. Furthermore, ordinary data collection-analysis regimes that involve interviews and observation using the naked human eyes take long for the data to be assembled, analyzed and accurately decoded (Shah et al., 2019). This is not viable in the fast-changing urban environment where delayed decisions fast result in traffic jams, garbage pile up, increased cartels-type crimes, air pollution, drug and substance trade and dependence, floods, building collapses, conflicts, disrupted supply of commodities, tax evasion among other ills. Artificial intelligence fills this gap through on the spot automated data collection, analysis and decision making (Zhu, 2021; Cugurrullo, 2020; Rosseau, 2020; Sharma et al., 2020). The data is collected from people's electronics (phones, iPads, TVs and laptops), using CCTV cameras spread across cities as well as using tax and trade related data. Aided by internet technology, digital television use, computing and mobile telephony that characterize the lives the urban majority today, every action or inaction by all individuals generates big data that is analyzed every passing second and used to plan the affairs of cities across the globe. China leads the world in integrating AI to urban planning and governance (Bacchi, 2020). Klosterman (2015) projected that with emergence of such digital technologies, urban planning and governance is expected to be easier for future cities.

\subsection{Libraries}

Libraries are a major source of secondary data for undertaking urban planning research. They store both hard copy documents, as well as digital (soft) copy ones that one can read. Today, libraries are subscribed to online depositories with a wide variety of books as well as journal articles that one can read. They exist as individual, organization or public places. One can hence easily undertake literature review from whichever is available. It is noteworthy that libraries from across 
the globe have gone virtual. With a subscription, one is able to access cloud-based resources from the comfort of their location using gadgets such as phones, laptops, tablets or even kindles provided they have internet access. Such virtual resources have eased access to information and are a great facilitator of research and distance learning (Zhou, 2021; Owusu-Ansah et al., 2019).

(Parnell \& Pieterse, 2015) also acknowledge the role of private online depositories of maps, photos, videos and even statistical data on cities such as cityscapes, ESRI, Google Earth, base map depositories and other platforms. They enable researchers to have a real sense of encounter with cities across the globe that allows them access to a basis for undertaking the planning and development of their own cities. Furthermore, the physical and virtual depositories contain policy documents. These are another very important source of information on urban planning (Harding \& Nevin, 2015). Similarly, a review of census data contained in these information reservoirs gives planners, political leaders and even residents a better understanding of their population being planned for, their socioeconomic dispositions, concentration, risks and opportunities. Census data informs investment in urban development to ensure it meets the needs of everyone (Wilson, 2016). Like it, all other forms of literature can be reviewed as an important data source, Literature review has been and will continue being fundamental in policy and political decision making in urban planning and governance as noted by (Parnell \& Pieterse, 2015).

\subsection{Using Person-to-Person Interactions}

In addition to the above tools, a lot of information is as well gathered through interpersonal interactions. Such include stakeholder interviews which are the key in generating insights and informing urban planning strategic priorities. Public, contractors (sector business community) and end user participation in planning and governance is one of the key condiments in this regard (Yang, 2014). Furthermore, stakeholders engage in focus group discussions (Lachapelle \& Mastel, 2019), professional events and networks such as seminars, workshops, conferences, roundtables, academic paper presentations, side talks and informal chit-chats all of which are a very important sources of urban planning insight (Rabinowitz, 2021; Alston, 2019; Shah et al., 2019). Additionally, exhibitions, symposia and design competitions (both virtual and face to face) are a good avenue for highlighting breakthroughs and systemic challenges in urban planning, design and development. Exposure to them triggers inquisitiveness in planners which then breed new and more advanced innovations (Hein, 2015).

\section{Conclusion}

The urban research methodologies are standard ways in which one can consistently undertake an inquiry across the urban landscapes of the globe. This is furthered by metrocentric and global cities ideals which tend to agglomerate urban cities as a set and judge them based on standard ideals which makes a city to 
be characterized as being beautiful, well planned, modern, well scaped, ancient/ historical, smart, or such other metrics. (Bunnell \& Maringanti, 2010) insist that in researching on cities, their uniqueness should be documented and enhanced in planning their future development. The two scholars are opposed to using the same pedagogy in researching and planning the future of all cities. Doing these will create the monotony of the global urban experience, and enhance risks of cities being befallen by eventualities. In addition, cities exist in diverse environmental and socio-economic ecosystems that shape their design, growth, development and daily governance. Such should be reflected in research outcomes and considered when undertaking research and developing policy and operational frameworks for global urban governance. Cities are contextual heritages with unique pasts and futures that should not be compromised through generalist research, planning, development and governance. They are unique perpetual heritage.

Modern research outputs acknowledge the world of cities and urbanspaces as being tiered and hierarchical. World citiness or the megacentric nature of any city is still an important indicator of liveability within cities, and helps expand investment in infrastructure among cities so as to compete with other global peers, and in the process, improve the living experiences of city dwellers and guests who should not feel lost in the newness or strangeness of things upon visiting a new city or countryside. Research in world citiness or megacentricism of cities becomes significant in this regard. The said research on urban and country planning is, however, constrained by the lack of financial resources, and a pool of researchers who are willing to go beyond secondary data collection into undertaking meaningful field surveys. Today, however, most of the research outputs in urban planning are a product of desk reviews by lazy academics. This laziness has, however, always been blamed on inadequate research funding for applied research and experimental development. Researchers can only produce within the scope of their capacities.

The urban environment works harmoniously when everyone's needs are understood and catered for in planning and urban development. Community-based enumeration/ethnographic studies, for instance, ensure that research outcomes meet the needs of both urban residents, decision-makers and knowledge professionals. This forms the epitome of participatory urban planning and governance. As much as possible, data that feeds into urban research findings should consult and incorporate the views of all cadres of stakeholders in developing collaborative city, national and global urbanization policies (Parnell \& Pieterse, 2015). This is unlike the traditional (old notion) ivory tower approach to urban studies where planners in city halls had all the say. Luckily, research and design alternatives for urban planning and development are increasingly permeating the academia and communities where talented and passionate individuals and groups are progressively engaged by state and private entities (including universities) to conceive, research on, design and implement projects and policies, including for 
national and city administrations. The urban planning discipline has also been democratized increasing the supply of trained experts to undertake meaningful research and innovate new outputs across the urban governance spectrum.

In addition to the above gains, it is noteworthy that traditional research methods still have immense utility in shaping the future of urban planning. They form a strong foundation from which emerging approaches will sprout. The fast-paced changes in methodology and tools however create a gap in research through the creation of more complex research tools and outcomes that can only be understood and utilized by a few technical and political elites in the urban planning and governance world. The ordinary citizen that investments in urban planning, design and development are supposed to help is often left wowed, flabbergasted and unable to consume these technologies. This Increasing complexity of the urban environment occasioned by constant research and innovation without involving the masses is fast making the urban space unusable, especially for the old, poor and technologically 'illiterate' folks (The Asean Post, 2018; Klosterman, 2015). This is common in fast emerging economies of the global south.

Based on the above analogy, there is a need to address the plight of those who cannot cope with the fast-paced evolution of the urban environment. They have so far not aggressively and deliberately been made to adjust, and will consequently always feel lost in the digital urban or even rural world where technologies are taking over the running of their used-to-be-familiar societies (Ming, 2021; Perez, 2019). The existence of a large majority of financially, physically, mentally or socially handicapped consumers of the urban space who lack the huge capital required to acquire and use these technologies also means that society will increasingly be unfairly dichotomized (Perez, 2019; Gibbs, 2018; Leyl, 2014). This reflects on the negative side of technology and innovations that we blindly integrate into urban environments without considering their negative impacts. Unfortunately, computer-based models on integrating such populations can rarely accurately predict their challenges (Klosterman, 2015). This calls for the deliberate retention and incorporation of human-led studies on the urban feel even as we allow AI to lead the way in solving urban problems as demonstrated by the cited experiences in Indonesia, Malaysia and China.

\section{Conflicts of Interest}

The authors declare no conflicts of interest regarding the publication of this paper.

\section{References}

Alpaydın, U. A. R., Atta-Owusu, K., \& Moghadam-Saman, S. (2018). The Role of Universities in Innovation and Regional Development: The Case of Rogaland Region. RUNIN Working Paper Series, Vol. 2018. https://doi.org/10.3990/4.2535-5686.2018.05

Alston, J. M. (2019, February 28). What's the Difference between a Conference, a Seminar, a Workshop and a Symposium? Conference Monkey. 
https://conferencemonkey.org/blog/whats-the-difference-between-a-conference-a-semi nar-a-workshop-and-a-symposium-1075915

Alves, B. B., De Oliveira, P. F., \& Fioravanti, G. (2017). E-Commerce Is Booming. What's in it for Urban Transport? World Bank Blogs. https://blogs.worldbank.org/transport/e-commerce-booming-what-s-it-urban-transport

Andrew, C. O., \& Hildebrand, P. E. (1983). Planning and Conducting Applied Agricultural Research. Canadian Journal of Agricultural Economics, 31, 275-277.

Bacchi, U. (2020, December 3). "I Know Your Favorite Drink": Chinese Smart City to Put AI in Charge. Thompson Reuters Foundation. https://news.trust.org/item/20201203131328-4n7on/

Baimyrzaeva, M. (2018). Beginners' Guide for Applied Research Process: What Is It, and Why and How to Do It? University of Central Asia, 10-26.

Bentley, J. P., Gulbrandsen, M., \& Kyvik, S. (2015). The Relationship between Basic and Applied Research in Universities. Higher Education, 70, 689-709 (21 pages). https://doi.org/10.1007/s10734-015-9861-2

Bhandari, P. (2021, July 7) An Introduction to Correlational Research. Scribbr. https://www.scribbr.com/methodology/correlational-research/

Bickman, L., \& Rog, D. J. (2008). Applied Research Design: A Practical Approach. In Approaches to Applied Research (pp. 3-43). Sage Publications. https://www.sagepub.com/sites/default/files/upm-binaries/23770 Ch1.pdf

Bodolica, V., \& Spraggon, M. (2021). Incubating Innovation in University Settings: Building Entrepreneurial Mindsets in the Future Generation of Innovative Emerging Market Leaders. Education + Training, 63, 613-631. https://doi.org/10.1108/ET-06-2020-0145

Boxall, P., \& Woodgates, M. (2015). Lagging Behind: Are UK Universities Falling Behind in The Global Innovation Race? PA Consulting Group.

Bunnell, T., \& Maringanti, A. (2010). Practising Urban and Regional Research beyond Metrocentricity. International Journal of Urban and Regional Research, 34, 415-420. https://doi.org/10.1111/j.1468-2427.2010.00988.x

Cao, K. (2013). Modern Urban Planning Theories. Planning Theory, 12, 321 -323. https://doi.org/10.1177/1473095212451042

Caulfield, J. (2020, March 13). A Guide to Ethnography. Scribbr. https://www.scribbr.com/methodology/ethnography/

Çetin, T. (2017). The Rise of Ride Sharing in Urban Transport: Threat or Opportunity? In H. Yaghoubi (Ed.), Urban Transport Systems. IntechOpen. https://doi.org/10.5772/66918

Cheetham, M., Wiseman, A., Khazaeli, B., Gibson, E. et al (2018). Embedded Research: A Promising Way to Create Evidence-Informed Impact in Public Health. Journal of Public Health, 40, i64-i70. https://doi.org/10.1093/pubmed/fdx125

Cugurrullo, F. (2020). Urban Artificial Intelligence: From Automation to Autonomy in the Smart City. Frontiers in Sustainable Cities, 3, Article No. 38. https://doi.org/10.3389/frsc.2020.00038

Elliott, M. (2018, February 9). History and Theories of Planning. https://www.svsapa.org/images/svs aicp/hIstory theory.pdf

ESRI (n.d.). What Is GIS? https://www.esri.com/en-us/what-is-gis/overview

Gibbs, N. (2018, January 21). The Impact of Technological Illiteracy. JOLT. https://jolt.richmond.edu/2018/01/21/the-impact-of-technological-illiteracy/ 
Gulbrandsen, M., \& Kyvik, S. (2010). Are The Concepts Basic Research, Applied Research and Experimental Development Still Useful? An Empirical Investigation among Norwegian Academics. Science and Public Policy, 37, 343-353.

https://doi.org/10.3152/030234210X501171

Harding, A., \& Nevin, B. (2015). Cities and Public Policy: A Review Paper. Government Office for Science, Foresight.

Hein, C. (2015). Urban Planning, Competitions and Exhibitions. In J. D. Wright (Ed.), International Encyclopedia of the Social \& Behavioral Sciences (2nd Edition, pp. 882-888). Elsevier. https://doi.org/10.1016/B978-0-08-097086-8.74055-4

Himmelreich, J. (2013) Good Urban Governance and Smart Technologies: A German City as a Best Practice Case of E-Government. In K. Akhilesh (Ed.), Emerging Dimensions of Technology Management (pp. 55-61). Springer. https://doi.org/10.1007/978-81-322-0792-4 4

Jiang, H. (2021). Smart Urban Governance in the "Smart" Era: Why Is It Urgently Needed? Cities, 111, Article ID: 103004. https://doi.org/10.1016/j.cities.2020.103004

Jiang, H., Geertman, S., \& Witte, P. (2020). Smart Urban Governance: An Alternative to Technocratic "Smartness". GeoJournal. https://doi.org/10.1007/s10708-020-10326-w

Klosterman, R. E. (2015). Urban Planning: Methods and Technologies. In J. D. Wright (Editor-in-Chief) (Ed.), International Encyclopedia of the Social \& Behavioral Sciences (2nd ed., Vol. 24, pp. 889-893). Elsevier.

https://doi.org/10.1016/B978-0-08-097086-8.74056-6

Lachapelle, P., \& Mastel, T. (2019, July 25). Using Focus Groups for Community Development. Community Planning and Zoning.

https://community-planning.extension.org/using-focus-groups-for-community-develo pment/

Leyl, S. (2014, February 27). How do Singapore's Poor Families Get By? BBC News. https://www.bbc.com/news/world-asia-26349689

Lloyd, A., Sloan, T., Antonioletti, M., \& McGilvary, G. (2013). Embedded Systems for Global E-Social Science: Moving Computation Rather than Data. Future Generation Computer Systems, 29, 1120-1129. https://doi.org/10.1016/j.future.2012.12.013

Makino, H., Tamada, K., Sakai, K., \& Kamijo, S. (2018). Solutions for Urban Traffic Issues by ITS Technologies. IATSS Research, 42, 49-60.

https://doi.org/10.1016/j.iatssr.2018.05.003

McCombes, S. (2019, May 8). How to Do a Case Study? Scribbr. https://www.scribbr.com/methodology/case-study/

McGinity, R., \& Solakangas, M. (2014). Introduction: "Embedded Research" as an Approach into Academia for Emerging Researchers. Management in Education, 28, 3-5. https://doi.org/10.1177/0892020613508863

Ming, T. E. (2021). The Big Read: Feeling Lost in a Digital World, Some Elderly Shun Technology. Today Online Newspaper.

https://www.todayonline.com/singapore/big-read-feeling-lost-digital-world-some-elde rly-shun-technology

Mucowska, M. (2021). Trends of Environmentally Sustainable Solutions of Urban Last-Mile Deliveries on the E-Commerce Market: A Literature Review. Sustainabilit, 13, Article No. 5894. https://doi.org/10.3390/su13115894

Nguyen, M. D. (2019). Public-Private Partnerships in Post-Socialist Urban Governance: Comparative Institutional Change in Leipzig, Shanghai and Ho Chi Minh City. In: Ti- 
purić, D. Hruška, \& Domagoj (Eds.), 7th International OFEL Conference on Governance, Management and Entrepreneurship: Embracing Diversity in Organisations (pp. 110-127). Governance Research and Development Centre (CIRU).

Odongo, J. O., \& Donghui, M. (2021). Infrastructure Dynamics of Urban Human Agglomeration in Nairobi, Kenya. IOSR Journal of Humanities and Social Science, 26, 1-12.

OECD (Organization for Economic Co-Operation and Development) (2002). Proposed Standard Practice for Surveys on Research and Experimental Development (p. 77). Organization for Economic Co-Operation and Development.

Owusu-Ansah, C., Rodrigues, A., \& Walt, T. V.D. (2019). Integrating Digital Libraries into Distance Education: A Review of Models, Roles, and Strategies. The Turkish Online Journal of Distance Education, 20, 89-104. https://doi.org/10.17718/tojde.557742

Palys, S. (2018). Basic Research. Simon Fraser University. https://www.sfu.ca/ palys/Basic\%20Research.pdf

Palys, T., \& Atchison, C. (2021). Research Methods in the Social and Health Sciences. Sage Publishing.

Parnell, S., \& Pieterse, E. (2015). Translational Global Praxis: Rethinking Methods and Modes of African Urban Research. International Journal of Urban and Regional Research, 40, 236-246. https://doi.org/10.1111/1468-2427.12278

Pedamkar, P. (2020). What is Qualitative Data Analysis. https://www.educba.com/what-is-qualitative-data-analysis/

Perez, G. (2019, August 16). Opinion: How Technology Discriminates Against Half of Our Population. JOLT.

https://www.mercurynews.com/2019/08/16/opinion-tech-needs-engineers-who-unders tand-struggles-of-women-and-people-of-color/

Pettersson, F., Hiselius, L. W., \& Koglin, I. (2018) E-Commerce and Urban Planning-Comparing Knowledge Claims in Research and Planning Practice. Urban, Planning and Transport Research, 6, 1-21. https://doi.org/10.1080/21650020.2018.1428114

Rabinowitz, P. (2021). Organizing a Conference. Community Toolbox. https://ctb.ku.edu/en/table-of-contents/structure/training-and-technical-assistance/con ferences/main

Raven, J., Stone, B., Mills, G., Towers, J., Katzschner, L., Leone, M., Gaborit, P., Georgescu, M., \& Hariri, M. (2018). Urban Planning and Design. In C. Rosenzweig, W. Solecki, P. Romero-Lankao, S. Mehrotra, S. Dhakal, \& S. Ali Ibrahim (Eds.), Climate Change and Cities: Second Assessment Report of the Urban Climate Change Research Network (pp. 139-172). Cambridge University Press. https://doi.org/10.1017/9781316563878.012

Rosseau, S. (2020, October 6). Where Artificial Intelligence Meets Urban Planning. University of Central Florida.

https://www.ucf.edu/news/where-artificial-intelligence-meets-urban-planning/

Schutt, R. K. (2018). Investigating The Social World: The Process and Practice of Research (9th ed.). University of Massachusetts Boston.

Shah, S., Modi, P., \& Shah, H. (2019). Big Data Analysis in Urban Planning. International Journal of Engineering Research \& Technology, 8, 355-359.

Sharma, G. D., Yadav, A., \& Chopra, R. (2020). Artificial Intelligence and Effective Governance: A Review, Critique and Research Agenda. Sustainable Futures, 2, Article ID: 100004. https://doi.org/10.1016/j.sftr.2019.100004

Smart City Hub (2017, May 1). These Are the Top Ten Urban Innovations. https://smartcityhub.com/technology-innnovation/these-are-the-top-10-urban-innovat ions/ 
Sotra, M. (2020, November 25). 7 Smart City Solutions to Reduce Traffic Congestion. https://www.sharedmobility.news/7-smart-city/

Stephen (2020, January 20). Quasi-Experimental Design. Philo Notes. https://philonotes.com/index.php/2020/01/20/quasi-experimental-designs/

The Asean Post (2018, May 2). Technology and an Ageing Singaporean Population. https://theaseanpost.com/article/technology-and-ageing-singaporean-population

Thomas, L. (2020a, May 8). What Is a Cross-Sectional Study? https://www.scribbr.com/methodology/cross-sectional-study/

Thomas, L. (2020b, May 8). What Is a longitudinal Study? https://www.scribbr.com/methodology/longitudinal-study/

Thomas, L. (2020c, July 31). An Introduction to Quasi-Experimental Designs. https://www.scribbr.com/methodology/quasi-experimental-design/

Vidican, G. (2009). The Role of Universities in Innovation and Sustainable Development. WIT Transactions on Ecology and the Environment, 120, 131-139. https://doi.org/10.2495/SDP090131

Villa, R., \& Monzón, A. (2021). Mobility Restrictions and E-Commerce: Holistic Balance in Madrid Centre during COVID-19 Lockdown. Economies, 9, Article No. 57. https://doi.org/10.3390/economies9020057

Wey, W. M. (2011). A Study of the Built Environment Design Elements Embedded into the Multiple Criteria Strategic Planning Model for an Urban Renewal. International Journal of Architectural, Civil and Construction Sciences, 5, 157-167.

WHO (World Health Organization) (2018). Embedded Research: An Innovative Approach to Improving Immunization Rates. WHO Alliance for Health Policy and Systems Research. https://www.who.int/alliance-hpsr/news/2018/embedded-hpsr/en/

Wilson, C. (2016). Understanding How Census Data Can Help in Making Planning Decisions. Michigan State University.

World Bank (2020, December 4). Government Objectives: Benefits and Risks of PPPs. https://ppp.worldbank.org/public-private-partnership/overview/ppp-objectives

Yang, R. J. (2014). An Investigation of Stakeholder Analysis in Urban Development Projects: Empirical or Rationalistic Perspectives. International Journal of Project Management, 32, 838-849. https://doi.org/10.1016/j.ijproman.2013.10.011

Zeleza, P. T. (2017). Positioning Universities as Engines of Innovation for Sustainable Development and Transformation. Journal of Higher Education in Africa/Revue de l'enseignement supérieur en Afrique, 15, 1-22.

Zhou, J. (2021). The Role of Libraries in Distance Learning During COVID-19. Information Development. https://doi.org/10.1177/02666669211001502

Zhu, W. (2021). Artificial Intelligence and Urban Governance: Risk Conflict and Strategy Choice. Open Journal of Social Sciences, 9, 250-261.

https://doi.org/10.4236/jss.2021.94019 